
\title{
R Research S Surare \\ Investigation on Potential Effect of Cell Shape and Size on the Residual Stress in Solid Oxide Fuel Cells
}

khaled azari ( $\square$ khaledazari@gmail.com )

Islamic Azad University Branch of Kermanshah https://orcid.org/0000-0002-1303-4328

Hamid Abdoli

NRI: Niroo Research Institute

Morteza Torabi

NRI: Niroo Research Institute

Shahriar Bozorgmehri

NRI: Niroo Research Institute

\section{Research Article}

Keywords: Solid oxide fuel cell, Residual stress, Cell size, Cell shape, X-ray diffraction

Posted Date: October 5th, 2021

DOl: https://doi.org/10.21203/rs.3.rs-923119/v1

License: (c) (1) This work is licensed under a Creative Commons Attribution 4.0 International License.

Read Full License 


\section{Abstract}

In the manufacturing process of solid oxide fuel cells (SOFCs), the residual stresses and curvature are developed in components due to the differences in material properties of cell layers. Significant residual stress may lead to the formation of cracks in the cell layers and facilitates cell fracture. In this work, the changes of the residual stress in the electrolyte of the anode-supported planar solid oxide fuel cells are experimentally determined at room temperature. The " $\sin ^{2} \psi$ " technique of X-ray diffraction method is employed to measure the residual stress in the half-cell samples. Several cells with different sizes and shapes are investigated to evaluate the potential impact of cell size and cell shape on the thermal residual stress. Because investigation on the changes of the residual stress and curvature state in the scaling up process of cell is crucial for commercial use. Values of about - $610 \mathrm{MPa}$ are determined for an electrolyte layer on an oxidized $\sim 400 \mu \mathrm{m}$ thick anode substrate. The results reveal that in spite of the effect of size and shape on the radius of curvature, these parameters have no significant effect on the residual stress level.

\section{Introduction}

A solid oxide fuel cell (SOFC) is a high-efficient electrochemical device that directly converts the chemical energy of fuels such as hydrogen and natural gas into electrical energy. In various configurations and designs, anode-supported planar SOFCs are widely used due to their higher power density and lower manufacturing cost [1-4].

Residual stresses are developed during the manufacturing process of the cells due to the thermo-elastic mismatch between the cell layers [5-11]. These residual stresses can result in performance degradation as a result of delamination [11] or the formation of cracks in the cell layers $[3,11]$ and in the extreme case may lead to the complete deterioration of the cell [12-14].

In the case of the anode-supported cells, much attention has been paid to the residual stress distribution after the cell fabrication process at room temperature and/or during its high temperature operation, especially in the electrolyte and anode layers.

Figure 1 shows a schematic cross-section of the residual stress distribution in an anode-supported cell at room temperature. The stress is compressive in the electrolyte layer and its value does not change significantly through the electrolyte thickness. The anode experiences tensile stress towards the electrolyte and compressive stress towards its free surface. The stress level at the free surface is lower than the stress level at the interface $[6,15,16]$.

For conventional anode (Ni/YSZ) and electrolyte (YSZ) materials, depending on the fabrication procedure and cell design, the maximum compressive stress in the electrolyte is as high as $500-700 \mathrm{MPa}[6,12$, 15-20]. The maximum tensile and compressive stresses in the anode are respectively about 20-100 $\mathrm{MPa}$ and 10-50 MPa $[6,12,15,16,20,21]$. 
Figure 2 shows a similar trend for residual stress distribution in an anode-supported cell at operating temperature (i.e. $800^{\circ} \mathrm{C}$ ). However, the operating temperature reduces the absolute stress level by about $50 \%[15,19,20]$ or more $[10]$.

During cell operation, chemical stresses (e.g., redox and chemical expansion) and thermally induced stresses are also superimposed to the residual stresses. These stresses are the major cause of the failure of the cell $[22,23]$ and should not exceed the strength of the materials $[18,19,24,25]$. Since the residual stress significantly affects the magnitude and distribution of stresses in the cell at operating conditions [26], estimation of residual stress at room temperature would be beneficial to calculate the stress in the anode-supported cells under operating conditions $[12,27,28]$.

The effects of different factors such as layers thickness, using an additional layer, reduction and reoxidation, applying different additives, sintering temperature, cell configurations and fabrication method on the residual stress of anode supported cells have been studied.

Zhang et al. [12] developed an analytical model to predict the residual thermal stresses in a single solid oxide fuel cell. They investigated the influence of the thickness of each layer on the residual stress distributions in the cell. In a similar study, Fan et al. [4] calculated the relationship between the residual stresses and the thicknesses of different cell components at room temperature. Laurencin et al. [20] proposed a numerical model to study the risk of cell failure due to residual stresses and investigated the effect of electrolyte thickness on the risk of anode failure. Severson et al. [16] developed a structural model for analysis of residual stresses in anode- and electrolyte-supported planar SOFCs and studied residual stress distribution for different thickness combinations.

Malzbender et al. [29] showed that applying an additional layer, as a support for the anode layer, compensates the cell curvature. However, the average residual tensile stress in the anode increases, which could lead to a larger fracture probability of the anode layer. Sun et al. [30] compared the effect of thermal cycling on residual stress and distortion in a standard 3-layer cell and one with an additional layer. Charlas et al. [31] analyzed and discussed the influence of an additional layer on the residual stresses in 4 layers half-cells.

Malzbender et al. [32] studied the influence of the reduction and re-oxidation on microstructure and residual stresses in the anode-supported cells. Fischer et al. [19] showed that the reduction of $\mathrm{NiO}$ to $\mathrm{Ni}$ in the anode reduces the absolute stress level in the electrolyte by $10 \%$ at room temperature. Hatae et al. [33] investigated the effect of anode expansion due to the re-oxidation on the residual stress in the electrolyte. Sun et al. [30] studied the effect of reduction of the supports on the electrolyte residual stress. Villanova et al. [34] investigated the change of residual stress in the electrolyte layer, after manufacturing, reduction and re-oxidation of the anode layer, using X-ray diffraction. Wang et al. [35] studied the residual stress variations during reduction at different temperatures and different operation time intervals. Fan et al. [4] calculated the residual stresses at room temperature caused by the manufacturing before and after the reduction and concluded that the reduction of $\mathrm{NiO}$ to $\mathrm{Ni}$ in the anode reduces the absolute stress level in the cell by $20 \%$. Xiang et al. [15] derived an analytical model to study the residual stress during anode 
reduction. Shang et al. [8] described the stress state in electrolyte as a result of the competition between the oxidation-induced stress and thermal residual stress. Frandsen et al. [10] showed that the residual stresses are relaxed at the point of chemical reduction of NiO-YSZ to Ni-YSZ.

He et al. [9] showed that adding $\mathrm{Al}_{2} \mathrm{O}_{3}$ in NiO-YSZ support materials affected the thermal expansion mismatch and reduced the residual stress in the cell. Cologna et al. [36] tailored the electrolyte composition by adding a fraction of fine powders to coarse powders to reduce the sintering stresses.

Yakabe et al. [27] studied the effect of sintering temperature on the calculated residual stress in the electrolyte at room temperature with X-ray measurements. Malzbender et al. [24] determined residual stress of half-cells with oxidized anode as a function of temperature.

Fujita et al. [37] and Somekawa et al. [38] estimated and compared residual stresses in the electrolytes of segmented-in-series solid oxide fuel cells (SIS-SOFCs) and usual anode-supported cells at room temperature by X-ray diffraction. Nakajo et al. [39] used a model based on the Euler-Bernoulli theory to study the residual stresses in the cell layers. Using the temperature-dependent mechanical properties of materials has enabled the study of the residual stress in several anode-supported SOFC configurations. Menzler et al. [40] developed a novel route to fabricate anode-supported solid oxide fuel cells, and measured the residual stresses in the electrolyte after sintering, before and after flattening. The stress level is significantly reduced in comparison to the data obtained for half-cells manufactured via the classical route.

Fischer et al. [19] showed that the flattening procedure of the SOFCs to remove the warp essentially does not change the residual stress level; however, reduces the in-plane fluctuation. Moon et al. [41] concluded that applying compressive force during co-firing can affect the residual stress distribution. The co-fired cell under optimal pressure showed homogeneous stress distribution. Shin el al.[2] showed that the roll calendaring process can produce cells with lower and more uniform residual stress compared to the conventional uniaxial press.

Many researchers have developed equations for calculating the residual stress and radius of curvature during the sintering process based on fundamental stress-strain relations $[15,29,36,42,43]$. Using these equations, the impact of different parameters on residual stress and radius of curvature were investigated, including layer thickness, cell configuration, sintering temperature and material properties. These equations do not take into account the dimensions and geometry of cell and implicitly assume that the size and geometry do not affect residual stress and radius of curvature.

However, some experiments showed that the dimension and geometry of cell affect the radius of curvature. Arias et al. [44] showed that the increase in cell diameter increases the radius of curvature. Converting deflection data of Moon et al. [41] and Orui et al. [45] into the radius of curvature demonstrated that the radius of curvature increases with increasing dimension. Mücke et al. [46] showed that the radius of curvature of the horizontally sintered specimens is three times higher than the freehanging samples. This difference is attributed to the effect of gravity and the weight of the samples. 
Molla et al. [7] presented an improved model that the effect of weight of the sample (gravity) on the kinetics of distortion is considered. Even under identical conditions, large cells are received more force due to the gravity effect. Malzbender [47] also investigated the effect of cell geometry on the warpage behavior of cells.

On the other hand, the commercial cells are usually much larger than the samples made in the laboratories or used in the research experiments. So, while researchers use small-size cells to conduct preliminary studies on the effect of various parameters on cell performance, it is still necessary to enlarge the cell size for practical and commercial use. Any changes of the residual stress and curvature state in this scaling up process should be investigated. Regarding the effect of dimension on the radius of curvature and the relationship between curvature and residual stress, we experimentally investigated the potential effects of the shape and size of ceramic cells on the residual stress.

In this work, we report our evaluation of the residual stresses in the electrolyte of anode-supported solid oxide fuel cells, which reveals the effect of the shape and size of cell on residual stresses. All cells have been fabricated by the conventional tape casting and co-sintering method. The conditions of the co-firing and tape-casting processes were identical for all specimens. We used the X-ray diffraction method to measure the residual stresses in the electrolyte of the anode-supported cell. This technique has been widely used to evaluate the residual and thermal stress in solid oxide fuel cells $[6,17-19,48-50]$.

\section{Materials And Method}

\subsection{Sample preparation}

Commercial 8YSZ (FCM, USA) powder with a surface area of $6.7 \mathrm{~m}^{2} \mathrm{gr}^{-1}$ and NiO-YSZ cermet powder (FCM, USA) with a surface area of $2.4 \mathrm{~m}^{2} \mathrm{gr}^{-1}$ were used for the fabrication of the electrolyte and the anode layers, respectively. The electrolyte slurry was cast on a Si-coated Mylar sheet using a homemade tape caster. After drying, the anode slurry was cast on the electrolyte layer. Dried green half-cell was cut into suitable geometries to acquire the desired sizes and shapes after sintering. Further experimental details of the fabrication process are described elsewhere [51, 52].

Anode and electrolyte thicknesses of all samples are about $400 \mu \mathrm{m}$ and $30 \mu \mathrm{m}$, respectively. Specifications of nine fabricated half cells are shown in Table 1.

\section{Table 1}

General specifications of the half cells. 


\begin{tabular}{|lllll|}
\hline Specimen No. & Shape & $\begin{array}{l}\text { Dimension } \\
(\mathbf{m m})\end{array}$ & $\begin{array}{l}\text { Area } \\
\left(\mathbf{C m} \mathbf{}^{\mathbf{}}\right)\end{array}$ & Size \\
\hline $\mathbf{r}-\mathbf{1}$ & Rectangle & Length $=29.5$, Width $=18$ & 5.3 & Small \\
\hline $\mathbf{r - 2}$ & Rectangle & Length $=29.5$, Width $=18$ & 5.3 & Small \\
\hline s-1 & Square & Side $=23$ & 5.3 & Small \\
\hline s-2 & Square & Side $=23$ & 5.3 & Small \\
\hline c-1 & Circle & Diameter $=26$ & 5.3 & Small \\
\hline c-2 & Circle & Diameter $=26$ & 5.3 & Small \\
\hline c-3 & Circle & Diameter $=26$ & 5.3 & Small \\
\hline C-1 & Circle & Diameter $=105$ & 86.6 & Large \\
\hline C-2 & Circle & Diameter $=105$ & 86.6 & Large \\
\hline
\end{tabular}

\subsection{Residual stress measurement}

The residual stresses in the electrolyte of the anode-supported half cells were estimated using an X-ray Philips X'Pert diffractometer. The conventional $\sin ^{2} \psi$ method and iso-inclination technique were used and the Cu-Ka X-ray source was selected. In this method, a diffraction peak at a high $2 \theta$ angle is used because in this case, applying a large $\psi$ range is possible. [17]. For this purpose, a preliminary scan was first conducted from 90 to $140^{\circ}(2 \theta)$, which is displayed in Fig. 3. Based on the results of the preliminary

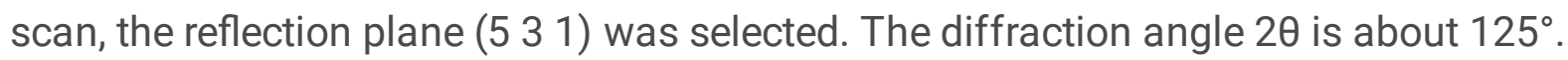

The residual stresses in the electrolyte were estimated using the following equation [27, 37]:

$\sigma=\frac{1}{d_{0}} \times \frac{E}{1+v} \times \frac{\partial d_{\psi}}{\partial \sin ^{2} \psi}$

where $d_{0}$ is the interplanar spacing under a stress-free condition, $\psi$ the tilt angle, $E$ is Young's modulus of $215 \mathrm{GPa}$ and $\mathrm{u}$ is Poisson's ratio of $0.3[19,37,40]$.

The stress was evaluated assuming a plane unidirectional stress field. Diffraction measurements were taken at $9 \psi$-angles (negative and positive inclinations) at equal distances in $\sin ^{2} \psi$ from 0 to 0.5 , using a step of $\Delta \theta=0.05^{\circ}$ in the neighborhood of $125^{\circ}$.

\section{Results And Discussion}


The shift of the diffracted ( $\left.\begin{array}{lll}5 & 3 & 1\end{array}\right)$ peak of YSZ with the change of $\psi$ measured for the sample $c 3$, is illustrated in Fig. 4. For all samples, the peak position shifted to a higher angle with increasing $\psi$.

For all samples, the corresponding $d$-spacing of various tilt angles $\psi$ were determined from the detected YSZ $\left(\begin{array}{lll}5 & 3 & 1\end{array}\right)$ diffraction peak positions. Figure 5 shows the $d-\sin ^{2} \psi$ diagram for sample $c 3$. As seen, the $d-$ spacing decreases with the increase of $\sin ^{2} \psi$, implying that the residual stress is compressive in this specimen. The residual stresses are estimated from the $d-\sin ^{2} \psi$ diagram using Eq. (1).

For small cells, the residual stresses in the electrolyte were calculated and listed in Table 2. The average value of $610 \mathrm{MPa}$ was calculated for residual stress in the electrolyte layer in this work. It can be seen that the estimated values are in agreement with the values reported in the literature for similar anodesupported cells. Yakabe [27] reported $774 \mathrm{MPa}$ for similar cells with anode and electrolyte thicknesses of $2000 \mu \mathrm{m}$ and $30 \mu \mathrm{m}$, respectively. According to Yakabe simulation [27], a decrease of anode layer thickness from $2000 \mu \mathrm{m}$ to $400 \mu \mathrm{m}$ (with constant electrolyte layer thickness of $30 \mu \mathrm{m}$ ) can reduce electrolyte stress level by about $150 \mathrm{MPa}$.

\section{Table 2}

List of the estimated residual stresses in the electrolyte for small cells.

\begin{tabular}{|llll|}
\hline Specimen No. & Shape & $\begin{array}{l}\text { Residual stress } \\
(\mathrm{MPa})\end{array}$ & $\begin{array}{l}\text { Error } \\
\text { (MPa) }\end{array}$ \\
\hline c-1 & Circle & 640 & \pm 39 \\
c-2 & Circle & 604 & \pm 20 \\
c-3 & Circle & 633 & \pm 21 \\
Average & & 626 & \\
r-1 & Rectangle & 626 & \pm 23 \\
r-2 & Rectangle & 643 & \pm 28 \\
\hline Average & & 635 & \pm 21 \\
\hline s-1 & Square & 577 & \pm 21 \\
\hline s-2 & Square & 553 & \\
\hline Average & & 565 & \\
\hline
\end{tabular}

The results in Table 2 reveals that the shape of the cells has little effect on the residual stresses and can be ignored. This is reasonable due to the nature of the residual stress which is caused by the difference in the material properties of the layers. 
It should be noted that all samples have been fabricated and sintered under identical conditions and all the effective parameters in the cell production route are the same. They are cut out of the same tape and sintered together in the furnace. However, the results of Table 2 also show that the samples with the same shape, have different residual stresses. This fluctuation in residual stress under the same experimental conditions has already been reported [19, 27, 30, 37]. Because, even under apparently identical conditions of the production process, microstructure may be inhomogeneous (e.g. density and distribution of the crack). Inhomogeneity in the microstructure of ceramic can affect the material properties and properties of different regions would be different. For example, the thickness of the tape as an effective factor on the residual stress level is not equal in length of a tape.

Therefore, the X-ray technique is unable to precisely detect the residual stresses due to changes in the cell shape. Although the stress is lowest for square cells, by taking into account the intrinsic errors of the method and the errors generated by assumptions (i.e. plane unidirectional stress field), no absolute conclusion can be made. In other words, the conventional $\sin ^{2} \psi$ method cannot measure the probable effect of cell shape on the residual stresses.

\subsection{Effect of cell size on the residual stress}

The X-ray stress evaluation method was also used to study the effect of cell size on the residual stress. The XRD patterns for residual stress measurement of a large cell (C1) are shown in Fig. 6.

Figure 7 shows the $d-\sin ^{2} \psi$ diagram for sample $C 1$. The estimated residual stress in the electrolyte was a compressive stress of $610 \mathrm{MPa}$ for the sample C1 and $618 \mathrm{MPa}$ for the sample C2.

Comparing this result for large cells with small cells data (Table 2) shows that the residual stress is independent of the cell size. This is also consistent with the previous simulations for anode-supported cells [27]. Simulation results reported by Yakabe and co-workers [27] show that when the cell size is larger than $5 \mathrm{~mm}$, the calculated stress is almost independent of the cell size.

Results of this section revealed that scaling up the cell size does not affect the residual stress state. However, this does not mean that scaling up the cells to larger sizes does not affect the probability of cell fracture. Because the increase in cell size is associated with the statistical probability of larger defects which can decrease the fracture stress of large cells in comparison with smaller specimens in an identical residual stress state [19].

On the other hand, the relationship between residual stress and warpage of the cell needs to be investigated, because due to the mismatch between the material properties of the individual layers, residual stresses and warpage are evolved during the manufacturing process. Some modifications, such as using additives to decrease the mismatch or decrease of sintering temperature, can reduce both residual stress and warpage $[9,27,40]$.

Some modifications, such as using a compensation layer, can reduce warpage, but increases residual stress [29]. Our results demonstrate that despite the effect of cell size on the warpage behavior, cell size 


\section{Conclusions}

Using large-scale SOFCs is very crucial for practical and commercial use. Changes of the residual stress and curvature state in the scaling up process of cells should be investigated. This work was an effort to address the stress state in the electrolyte layer of the anode-supported planar solid oxide fuel cell. The residual stress of the YSZ electrolyte was evaluated using the X-ray $\sin ^{2} \psi$ stress measurement method. The changes in the residual stress were measured to investigate the impact of cell size and cell shape on the residual stress.

The XRD measurements were carried out at room temperature in the electrolyte of half-cells. In the case of a $\sim 30 \mu \mathrm{m}$ thick electrolyte layer on an oxidized $\sim 400 \mu \mathrm{m}$ thick anode substrate, the estimated residual stresses in the electrolyte were compressive stresses of around $600 \mathrm{MPa}$. For our specimens, the change of cell shape without changing other parameters did not alter the stress states and the relative distributions. There was no obvious difference in residual stresses between the specimens with different shapes.

It was also found that the residual stress in the electrolyte of the anode-supported planar SOFC remained almost constant during the scale-up process and the change of cell size did not affect the residual stress level.

Based on the results of this study, it can be concluded that in spite of the effect of size and shape on the radius of curvature, these parameters do not affect the residual stress level.

\section{Declarations}

\section{Acknowledgements}

This work was financially supported by the Kermanshah Branch of Islamic Azad University under a research program entitled "Survey of Residual Stress in Solid Oxide Fuel Cells".

\section{References}

1. Huang Z, Luo L, Liu L et al (2018) Effect of $\mathrm{Al}_{2} \mathrm{O}_{3}$ addition on the non-isothermal crystallization kinetics and long-term stability of BCABS sealing glass for IT-SOFCs. J Adv Ceram 7:380-387

2. Shin J, Park JH, Kim J et al (2020) Suppression of processing defects in large-scale anode of planar solid oxide fuel cell via multi-layer roll calendering. J Alloys Compd 812:1-7

3. Ettler M, Timmermann $\mathrm{H}$, Malzbender $\mathrm{J}$ et al (2010) Durability of $\mathrm{Ni}$ anodes during reoxidation cycles. J Power Sources 195:5452-5467 
4. Fan P, Li G, Zeng Y et al (2014) Numerical study on thermal stresses of a planar solid oxide fuel cell. Int J Therm Sci 77:1-10

5. Hbaieb K (2015) Blister defect formation within partially stabilized zirconia film during constrained sintering. J Adv Ceram 4:76-82

6. Wei J, Osipova T, Malzbender J et al (2018) Mechanical characterization of SOFC/SOEC cells. Ceram Int 44:11094-11100

7. Molla TT, Frandsen HL, Bjørk R et al (2013) Modeling kinetics of distortion in porous bi-layered structures. J Eur Ceram Soc 33:1297-1305

8. Shang S, Lu Y, Cao X et al (2019) A model for oxidation-induced stress analysis of Ni-based anodesupported planar solid oxide fuel cell. Int J Hydrogen Energy 44:16956-16964

9. He CR, Wang WG, Wang $J$ et al (2011) Effect of alumina on the curvature, Young's modulus, thermal expansion coefficient and residual stress of planar solid oxide fuel cells. J Power Sources 196:76397644

10. Frandsen HL, Chatzichristodoulou C, Charlas B et al (2021) Fast relaxation of stresses in solid oxide cells through reduction. Part I: Macro-stresses in the cell layers. Int J Hydrogen Energy 46:1548-1559

11. Selçuk A, Merere G, Atkinson A (2001) The influence of electrodes on the strength of planar zirconia solid oxide fuel cells. J Mater Sci 36:1173-1182

12. Zhang T, Zhu Q, Lai W et al (2008) Stress field and failure probability analysis for the single cell of planar solid oxide fuel cells. J Power Sources 182:540-545

13. Villanova J, Sicardy O, Fortunier R et al (2010) Determination of global and local residual stresses in SOFC by X-ray diffraction. Nucl Instruments Methods Phys Res Sect B Beam Interact with Mater Atoms 268:282-286

14. Steinbrech RW (2008) Threshold fracture stress of thin ceramic components. J Eur Ceram Soc 28:247-252

15. Xiang Z, Haibo S, Fenghui W et al (2014) Curvature Reversal and Residual Stress in Solid Oxide Fuel Cell Induced by Chemical Shrinkage and Expansion. Fuel Cells 14:1057-1061

16. Severson H, Assadi M (2013) Analysis of Residual and Operational Thermal Stresses in a Planar SOFC. J Fuel Cell Sci Technol 10:061001-061014

17. Yakabe H, Baba Y, Sakurai T et al (2004) Evaluation of residual stresses in a SOFC stack. J Power Sources 131:278-284

18. Malzbender J, Steinbrech RW, Singheiser L (2009) A review of advanced techniques for characterising SOFC behaviour. Fuel Cells 9:785-793

19. Fischer W, Malzbender J, Blass $\mathrm{G}$ et al (2005) Residual stresses in planar solid oxide fuel cells. J Power Sources 150:73-77

20. Laurencin J, Delette G, Lefebvre-joud F et al (2008) A numerical tool to estimate SOFC mechanical degradation: Case of the planar cell configuration. J Eur Ceram Soc 28:1857-1869 
21. Greco F, Lund H, Nakajo A et al (2014) Modelling the impact of creep on the probability of failure of a solid oxide fuel cell stack. J Eur Ceram Soc 34:2695-2704

22. Kakaç S, Pramuanjaroenkij A, Zhou XY (2007) A review of numerical modeling of solid oxide fuel cells. Int J Hydrogen Energy 32:761-786

23. Delette G, Laurencin J, Murer S et al (2012) Effect of residual stresses on the propagation of interface cracks between dissimilar brittle materials: Contribution of two and three-dimensional analyses. Eur J Mech A/Solids 35:97-110

24. Malzbender J, Fischer W, Steinbrech RW (2008) Studies of residual stresses in planar solid oxide fuel cells. J Power Sources 182:594-598

25. Malzbender J, Steinbrech RW (2007) Advanced measurement techniques to characterize thermomechanical aspects of solid oxide fuel cells. J Power Sources 173:60-67

26. Clague R, Marquis AJ, Brandon NP (2012) Finite element and analytical stress analysis of a solid oxide fuel cell. J Power Sources 210:224-232

27. Yakabe H, Baba Y, Sakurai T et al (2004) Evaluation of the residual stress for anode-supported SOFCs. J Power Sources 135:9-16

28. Lin C, Huang L, Chiang L et al (2009) Thermal stress analysis of planar solid oxide fuel cell stacks: Effects of sealing design. J Power Sources 192:515-524

29. Malzbender J, Wakui T, Steinbrech RW (2006) Curvature of planar solid oxide fuel cells during sealing and cooling of stacks. Fuel Cells 6:123-129

30. Sun B, Rudkin RA, Atkinson A (2009) Effect of Thermal Cycling on Residual Stress and Curvature of Anode-Supported SOFCs. Fuel Cells 9:805-813

31. Charlas B, Frandsen HL, Brodersen K et al (2015) Residual stresses and strength of multilayer tape cast solid oxide fuel and electrolysis half-cells. J Power Sources 288:243-252

32. Malzbender J, Wessel E, Steinbrech RW (2005) Reduction and re-oxidation of anodes for solid oxide fuel cells. Solid State lonics 176:2201-2203

33. Hatae T, Matsuzaki Y, Yamazaki Y (2008) Study on electrochemical re-oxidation of anode-supported solid oxide fuel cells using oxide ion current. Solid State lonics 179:274-281

34. Villanova J, Sicardy O, Fortunier R et al (2011) X-ray diffraction determination of macro and micro stresses in SOFC electrolyte and evolution with redox cycling of the anode. Mater Sci Forum 681:2530

35. Wang X, Wang F (2011) Studies of half-cell for anode supported SOFC after reduction. Adv Mater Res 290:2511-2515

36. Cologna M, Sglavo VM, Bertoldi M (2010) Sintering and deformation of solid oxide fuel cells produced by sequential tape casting. Int J Appl Ceram Technol 7:803-813

37. Fujita K, Somekawa T, Hatae T et al (2011) Residual stress and redox cycling of segmented-in-series solid oxide fuel cells. J Power Sources 196:9022-9026 
38. Somekawa T, Fujita K, Matsuzaki Y (2013) Residual stress change with time of a segmented-in-series solid oxide fuel cell using an in situ X-ray stress measuring method. J Power Sources 221:64-69

39. Nakajo A, Van Herle J, Favrat D (2011) Sensitivity of stresses and failure mechanisms in SOFCs to the mechanical properties and geometry of the constitutive layers. Fuel Cells 11:537-552

40. Menzler NH, Malzbender J, Schoderböck P et al (2014) Sequential Tape Casting of Anode-Supported Solid Oxide Fuel Cells. Fuel Cells 14:96-106

41. Moon H, Kang DW, Park HG et al (2011) Stress and camber analysis of anode-supported electrolytes by tape-casting and co-firing techniques. Int J Hydrogen Energy 36:10991-10997

42. Lee SH, Messing GL, Green DJ (2004) Warpage Evolution of Screen Printed Multilayer Ceramics during Co-Firing. Key Eng Mater 264-268:321-330

43. Chang J, Guillon O, Rödel J et al (2008) Characterization of warpage behaviour of Gd-doped ceria/NiO-yttria stabilized zirconia bi-layer samples for solid oxide fuel cell application. J Power Sources 185:759-764

44. Aguilar-Arias J, Hotza D, Lenormand P et al (2013) Planar solid oxide fuel cells using PSZ, processed by sequential aqueous tape casting and constrained sintering. J Am Ceram Soc 96:3075-3083

45. Orui H, Nozawa K, Watanabe K et al (2008) Development of Practical Size Anode-Supported Solid Oxide Fuel Cells with Multilayer Anode Structures. J Electrochem Soc 155:B1110-B1116

46. Mucke R, Menzler NH, Buchkremer HP et al (2009) Cofiring of thin zirconia films during SOFC manufacturing. J Am Ceram Soc 92:S95-S102

47. Malzbender $J$ (2010) Curvature and stresses for bi-layer functional ceramic materials. J Eur Ceram Soc 30:3407-3413

48. Sumi H, Ukai K, Yokoyama M et al (2006) Changes of Internal Stress in Solid-Oxide Fuel Cell During Red-Ox Cycle Evaluated by In Situ Measurement With Synchrotron Radiation. J Fuel Cell Sci Technol 3:68-74

49. Yang YC, Lu LY, Hwang CS et al (2013) Residual stresses in the atmospheric plasma sprayed $\mathrm{NiO} / \mathrm{LDC}$ anode of the metallic supported solid oxide fuel cells. Surf Coatings Technol 231:193-200

50. Huang K, Harter HD (2010) Temperature-dependent residual stresses in plasma sprayed electrolyte thin-film on the cathode substrate of a solid oxide fuel cell. Solid State lonics 181:943-946

51. Azari K, Vaghasloo YA, Mohandesi JA et al (2015) The effect of cell shape on the warpage in solid oxide fuel cells. J Power Sources 279:64-71

52. Azari K, Mohandesi JA, Vaghasloo YA (2016) Size dependence of warpage in solid oxide fuel cell. J Power Sources 301:326-331

\section{Figures}




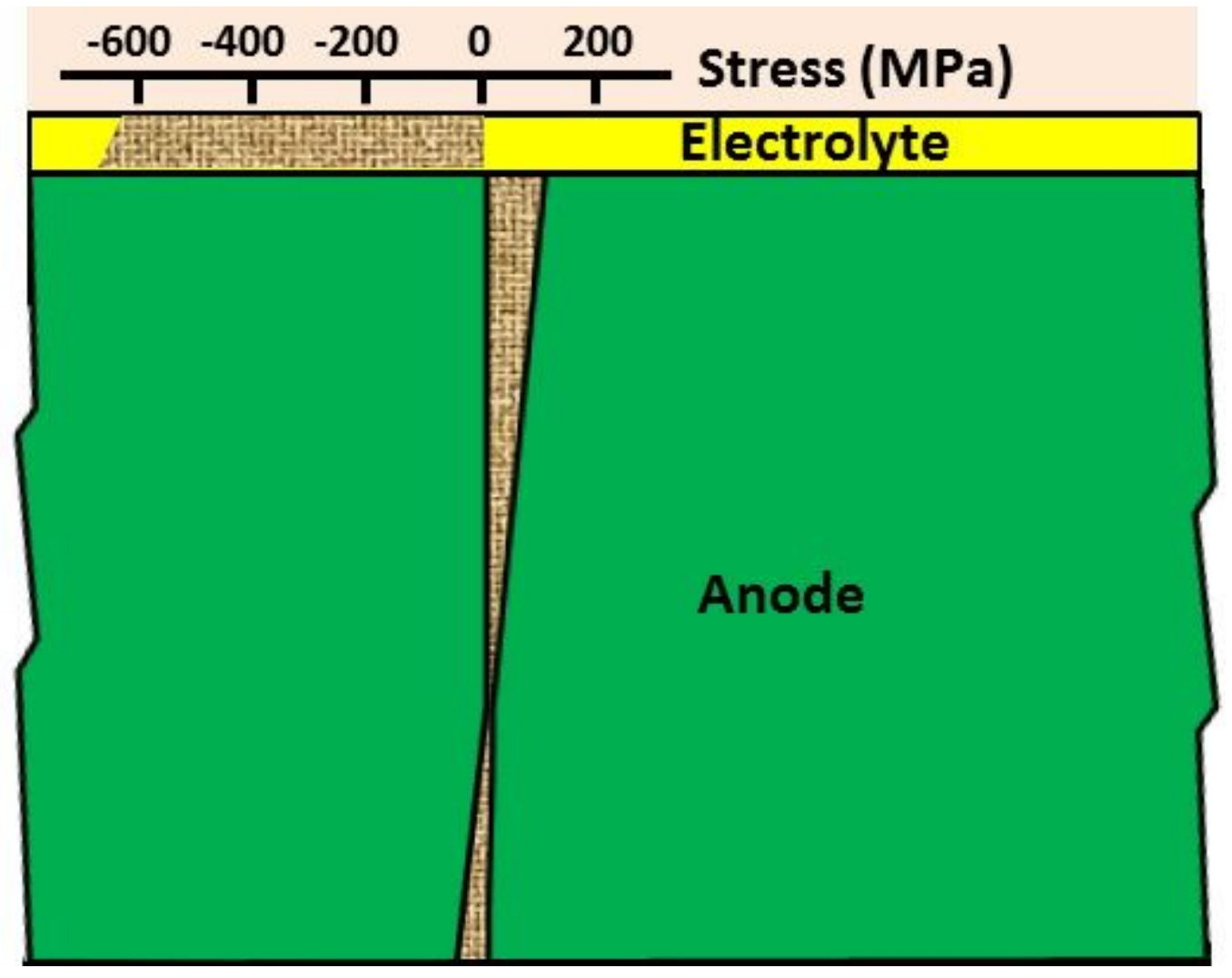

Figure 1

Schematic diagram of the cross-sectional view of the residual stress distribution in an anode supported cell at room temperature.

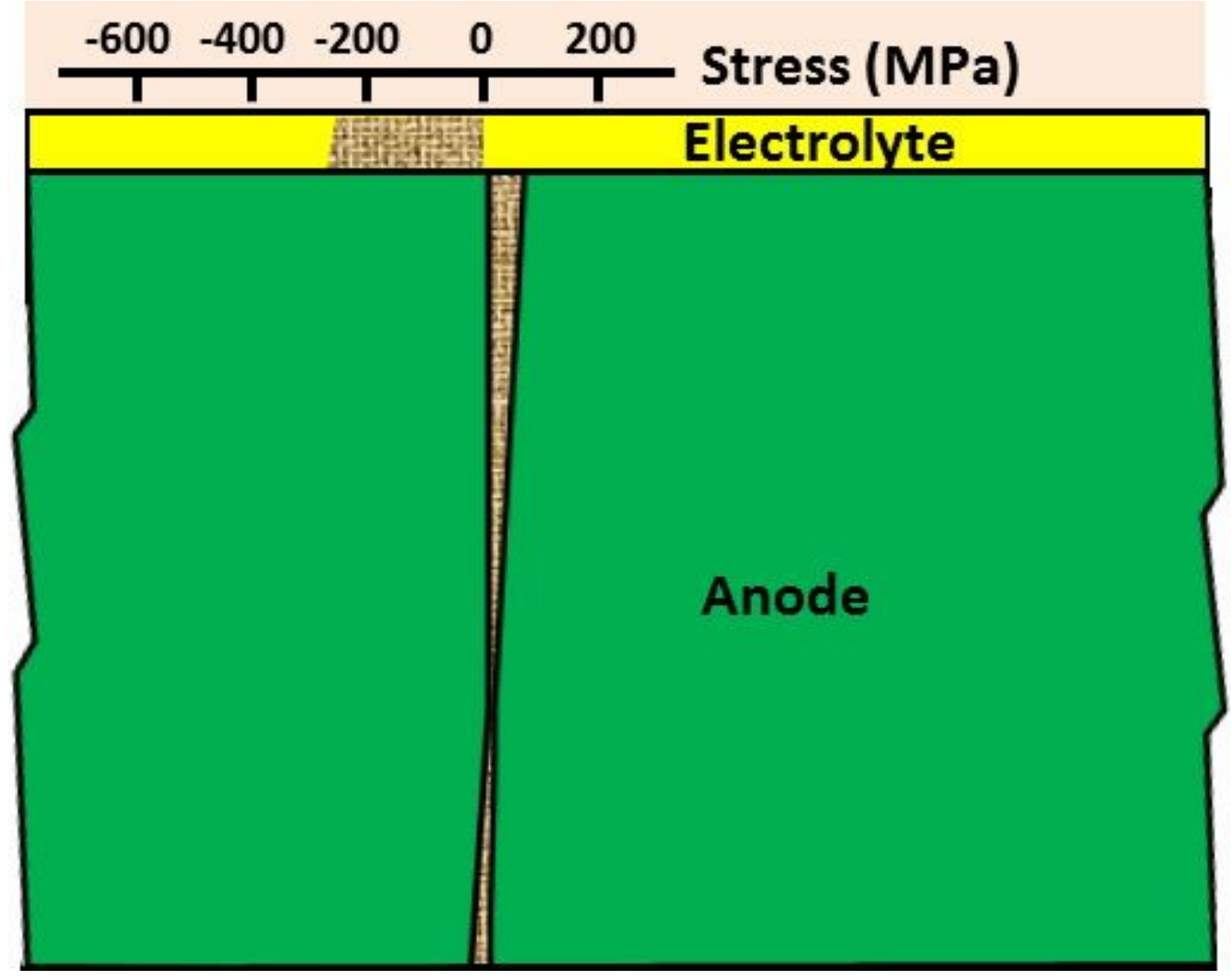


Figure 2

Decrease in overall residual stress level at working temperature (compare with Fig.1).

Counts

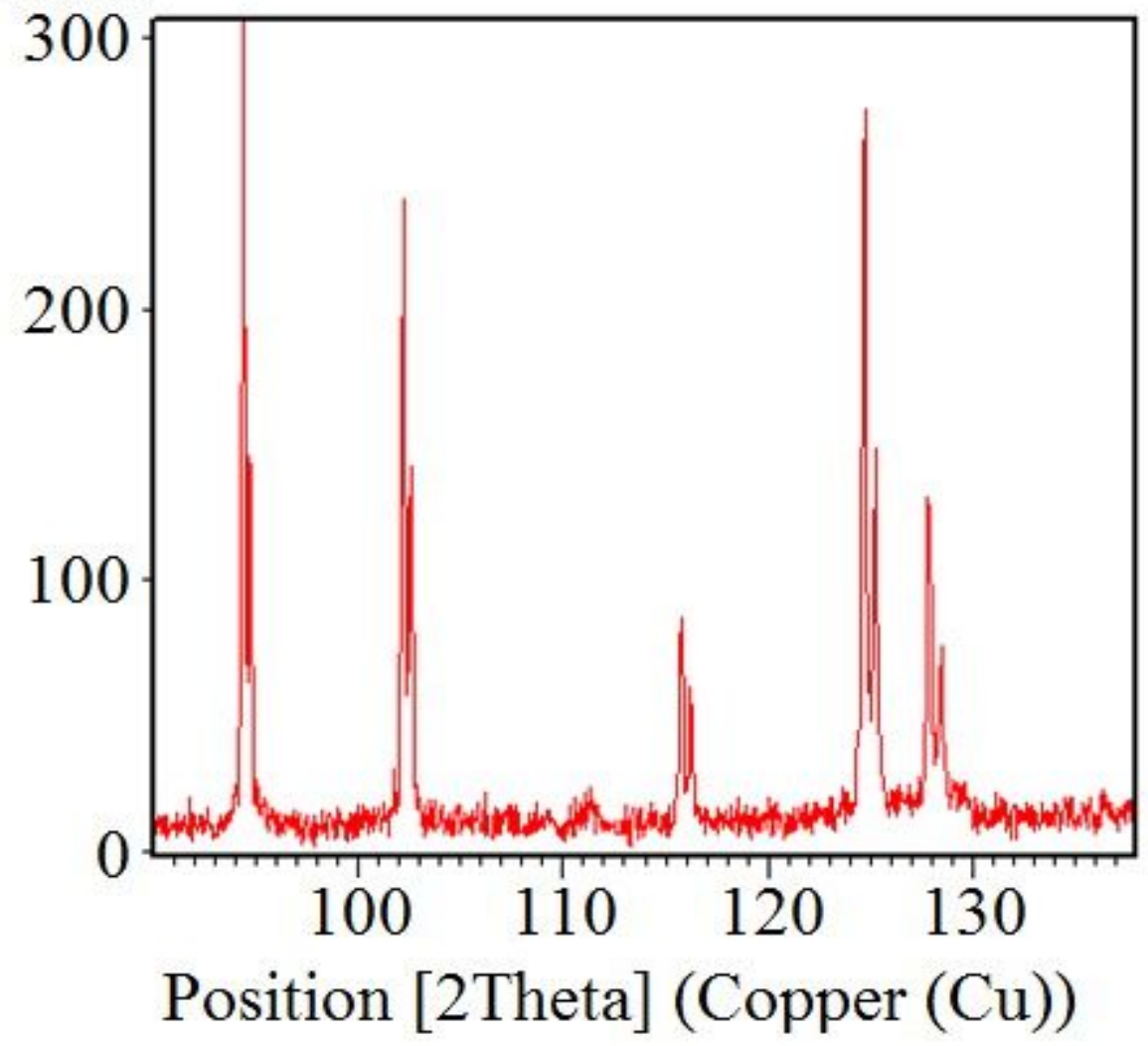

Figure 3

XRD pattern for the electrolyte of the half cell. 


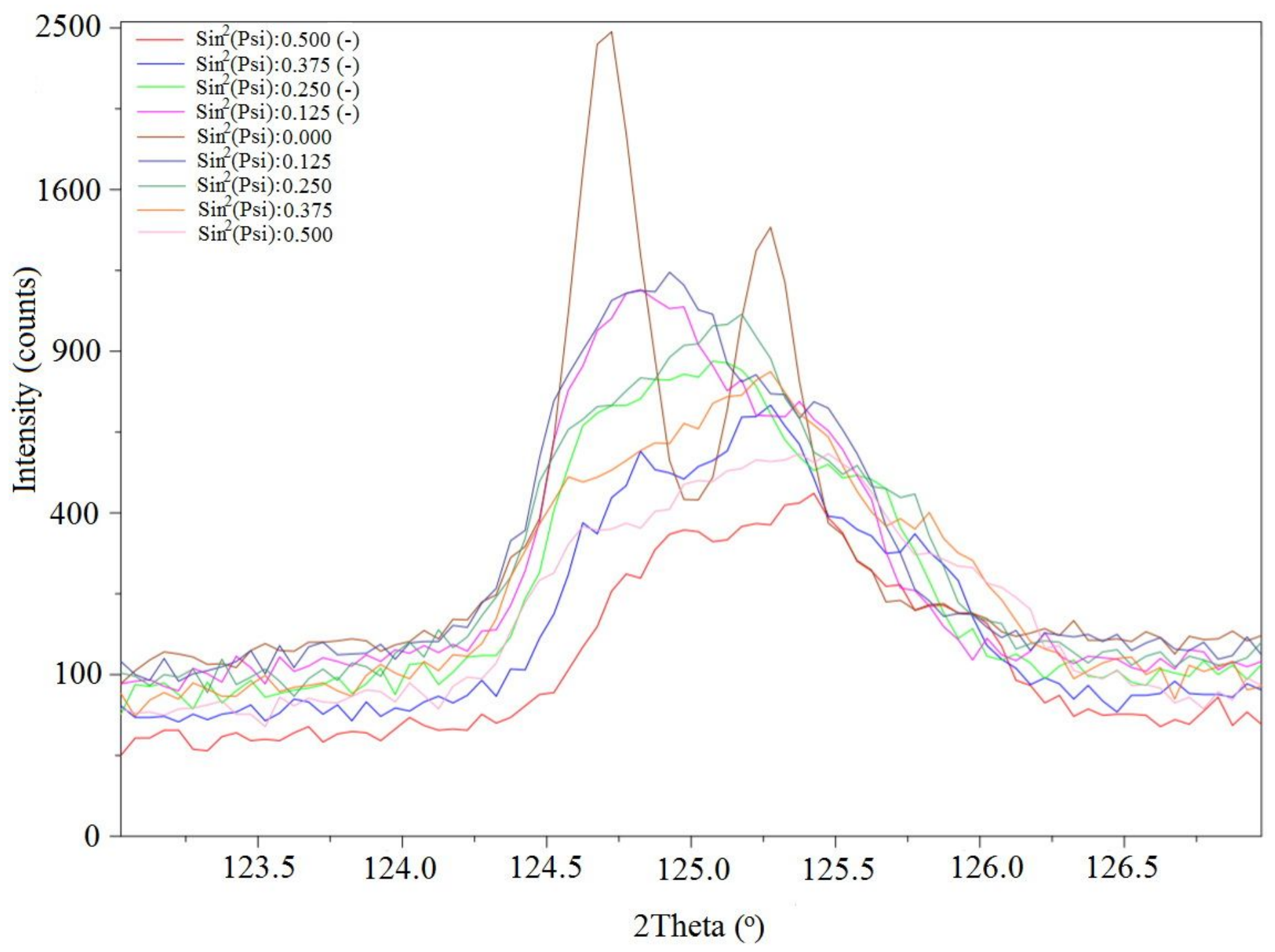

Figure 4

Change of the diffraction peak of YSZ (5 30 ) plane with the change of $\psi$ for the sample c3. 


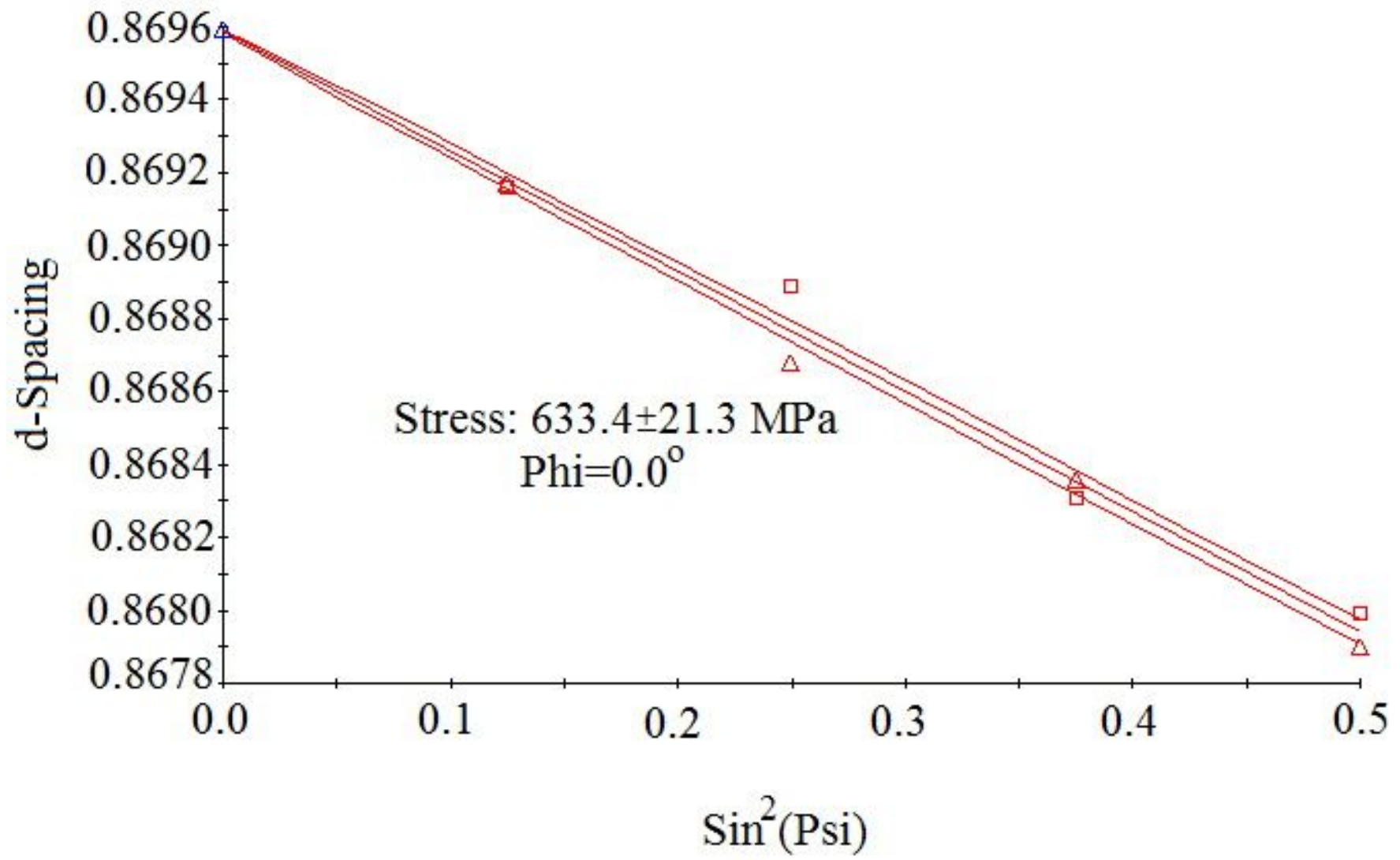

Figure 5

$\mathrm{d}-\sin 2 \psi$ diagram for sample $\mathrm{c} 3$. 


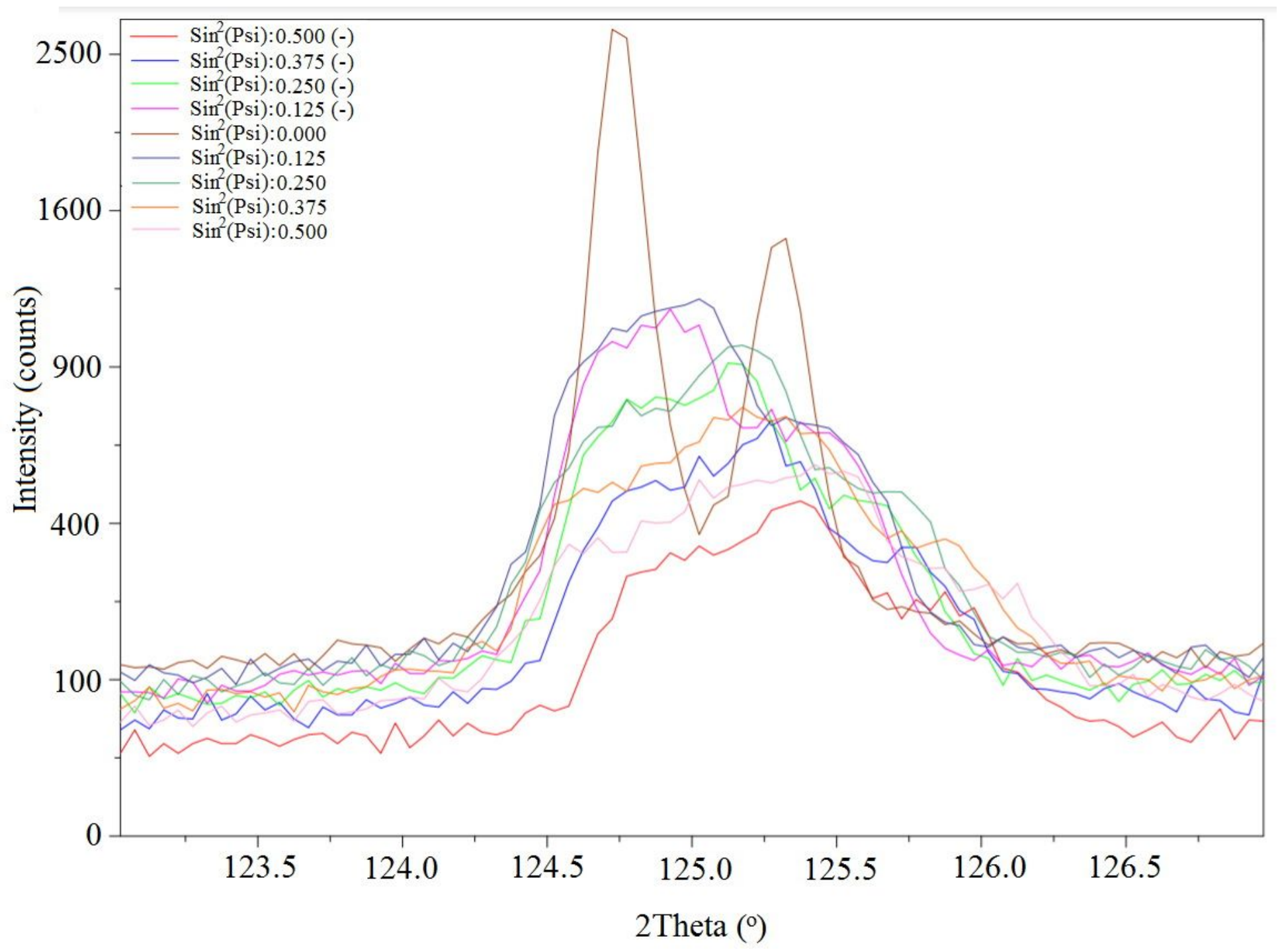

Figure 6

X-ray diffraction pattern of sample C1 at different $\psi$. 


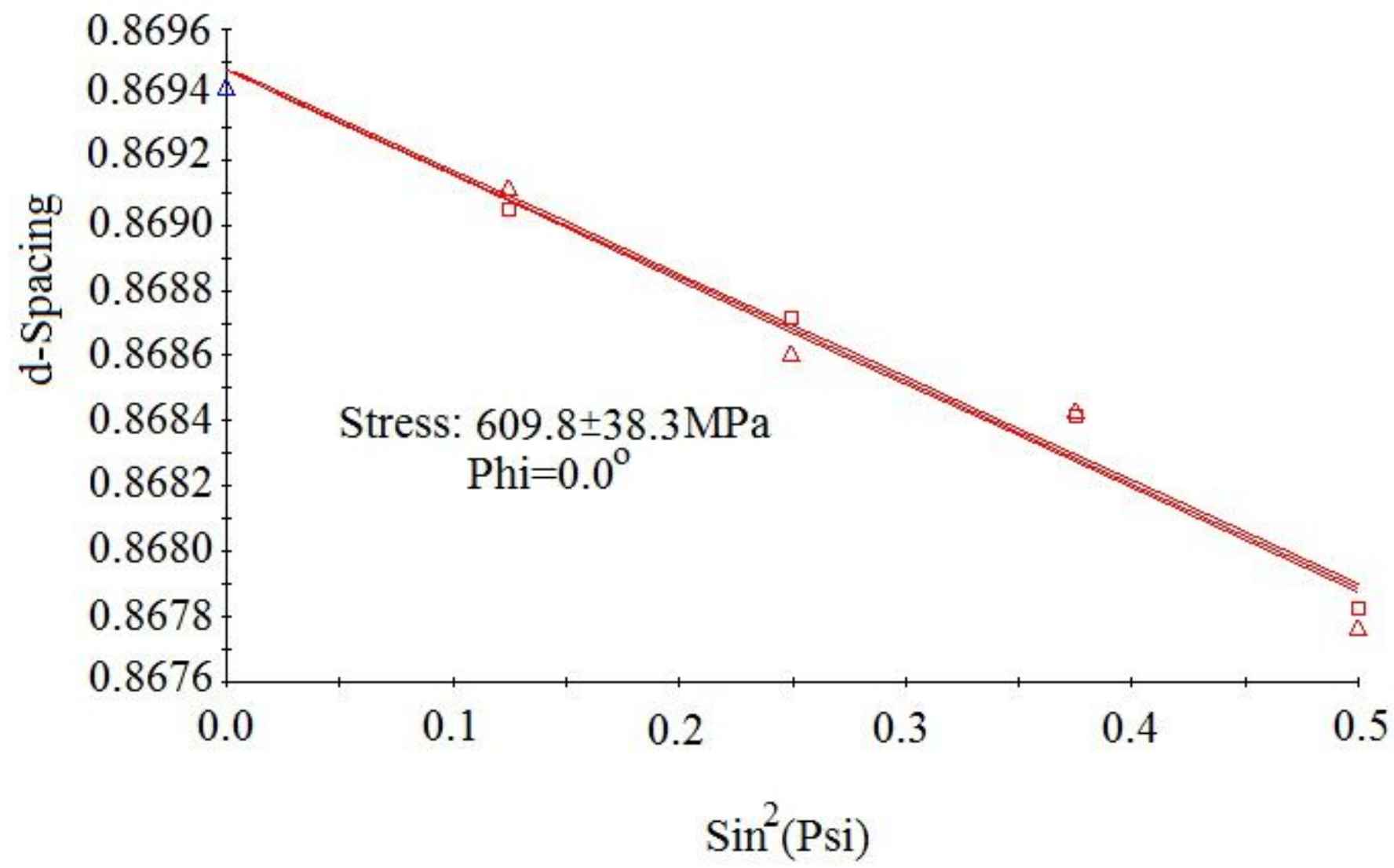

Figure 7

$\mathrm{d}-\sin 2 \psi$ diagram for sample $\mathrm{C} 1$. 